\title{
PWPI Promotes the Malignant Phenotypes of Lung Cancer Cells by Interacting with DVL2 and Merlin [Corrigendum]
}

Wei L, Li P, Luo Y, et al. Onco Targets Ther. 2020;13:10025-10037.

The authors have advised Figure 4 on page 10033 is incorrect due to errors at the time of figure assembly. Part A, second panel, the label "DVL2, p-DVL2" should read "p-DVL2,
DVL2", and the last panel in part E is missing a label. The correct Figure 4 is shown below.

The authors apologize for these errors and advise they do not affect the results of the paper.

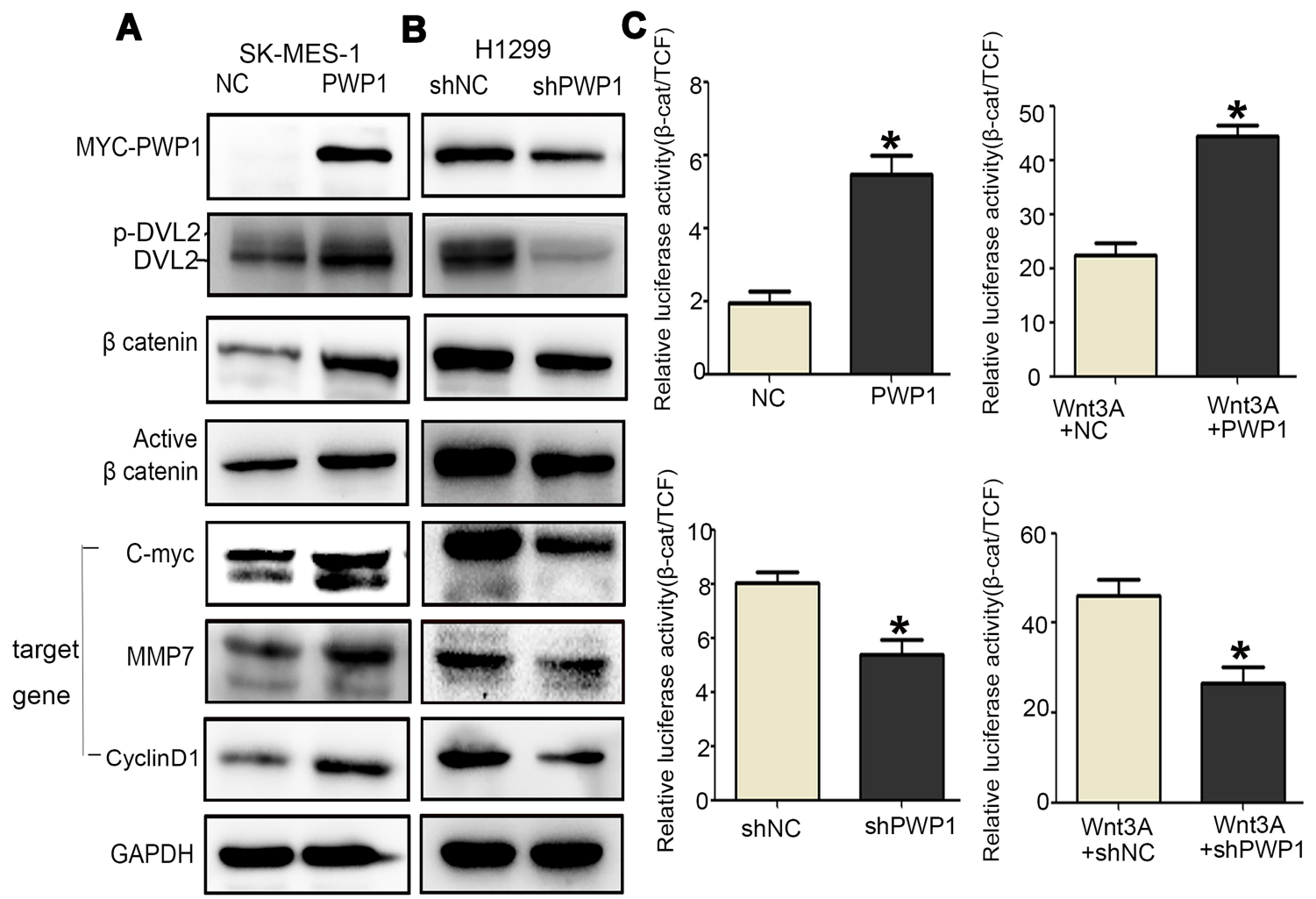

Figure 4 Continued. 
D

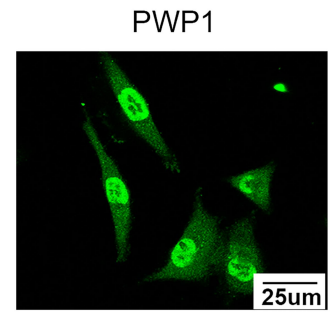

E

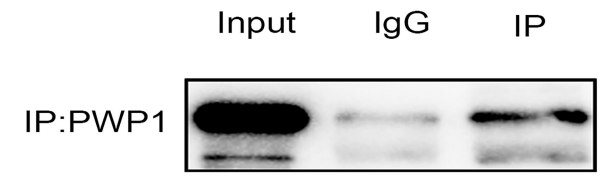

IB:DVL2

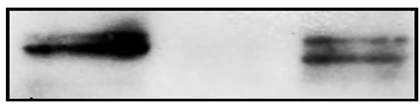

IP:DVL2

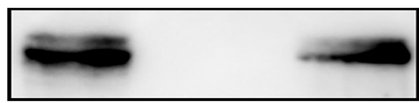

IB:PWP1

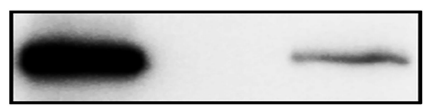

DVL2

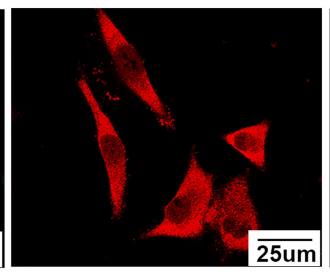

DAPI

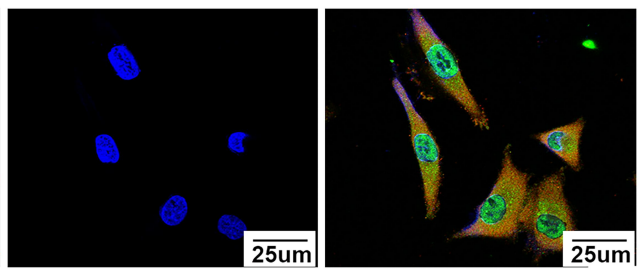

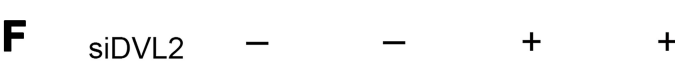

MYC-PWP1 - $\quad+\quad+\quad+\quad+$

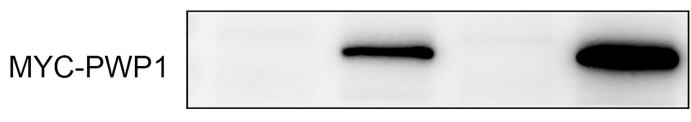

DVL2

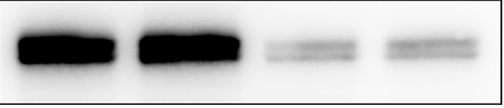

$\beta$ catenin

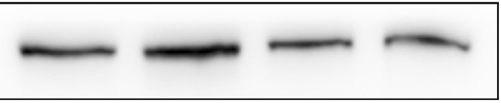

Active

$\beta$ catenin

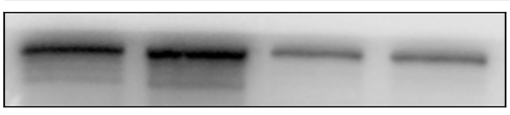

GAPDH

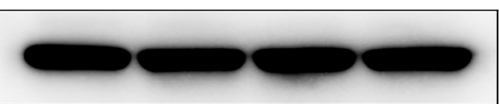

Figure 4 PWPI activates the Wnt signaling pathway by interaction with DVL2. After transfection of PWPI into SK-MES-I cell line, wb showed that the phosphorylation of DVL2 and Active $\beta$-catenin were upregulated, and the expression levels of target genes of Wnt pathway, C-myc, Cyclin DI and MMP7 were upregulated (A). After knocking down of PWPI into HI299 cell line, wb showed that the phosphorylation of DVL2 and Active $\beta$-catenin were downregulated, and the expression levels of target genes of Wnt pathway, C-myc, Cyclin DI and MMP7 were downregulated (B). GAPDH serves as a loading control. The grey value was measured using Image software. Luciferase gene-reporter assays showed that PWPI could activate the Wnt pathway, after knocking down PWPI, the Wnt pathway would be inhibited (C). Columns: mean numbers, Bar: SD. $(* \mathrm{P}<0.05)$. PWPI and DVL2 co-localized in the cytoplasm (D, magnification 600x). Co-ip testing confirmed the interaction between PWPI and DVL2 (E). Transfection of PWPI and knocking down DVL2 would offset the effects of PWPI on the Wnt pathway (F). Results are shown from three independent experiments.

\section{Publish your work in this journal}

OncoTargets and Therapy is an international, peer-reviewed, open access journal focusing on the pathological basis of all cancers, potential targets for therapy and treatment protocols employed to improve the management of cancer patients. The journal also focuses on the impact of management programs and new therapeutic agents and protocols on patient perspectives such as quality of life, adherence and satisfaction. The manuscript management system is completely online and includes a very quick and fair peer-review system, which is all easy to use. Visit http://www.dovepress.com/ testimonials.php to read real quotes from published authors. 